$\operatorname{R}_{\text {ESEA }}^{\text {RCH }}$ RTICL

Members of the Research Forum Associate Author :

${ }^{1}$ Department of Veterinary Anatomy, College of Veterinary and Animal Sciences, Parbhani (M.S.) India

AUTHOR FOR CORRESPONDENCE : P. N. Thakur,

Department of Veterinary Anatomy, College of Veterinary and Animal Sciences, Parbhani (M.S.) India Email : pravin_thakur75@ rediffmail.com

\section{Histomorphological and histochemical studies on isthumus of oviduct in Japanese quails}

\author{
P. N. Thakur, P. J. Kapadnis ${ }^{1}$ and N. M. Karad ${ }^{1}$
}

\begin{abstract}
The mucosa of each segment presented lamina epithelialis, lamina propria and lamina mucosae. The mucosa was thrown into folds viz., primary and secondary folds. The lamina epithelialis presented pseudostratified columnar ciliated epithelium was observed in isthmus, in both the groups of quail.
\end{abstract}

Key words : Histomorphological, Histochemical, Isthumus, Oviduct of Japanese quail

How to cite this paper : Thakur, P.N., Kapadnis, P.J. and Karad, N.M. (2019). Histomorphological and histochemical studies on isthumus of oviduct in Japanese quails. Vet. Sci. Res. J., 10(1) : 7-11, DOI : 10.15740/HAS/VSRJ/10.1/7-11. Copyright@2019: Hind Agri-Horticultural Society.

Paper History : Received : 02.02.2019; Revised : 12.03.2019; Accepted : 19.03 .2019 